\title{
From Atrocity Crimes to Human Rights: Expanding the Focus of the Responsibility to Protect
}

\author{
Kirsten Ainley \\ London School of Economics \\ k.a.ainley@1se.ac.uk
}

For publication in Global Responsibility to Protect 9(2) 2017.

\begin{abstract}
:
The Responsibility to Protect (R2P) was envisaged by its authors to encompass a wide range of human rights protections. In order to gain state support for the idea of the R2P, its focus was narrowed to the protection of populations from atrocity crimes. This article challenges the 'atrocity lens', arguing that the restricted focus is both practically and conceptually flawed. Practically, it has failed to inspire action in situations where there were good reasons to believe that atrocities were occurring. Conceptually, it has led to a counterproductive focus in R2P implementation on conflict and on particular actors within conflict. The article therefore explores the possibilities and implications of stretching the focus of R2P back to the broader vision found within the ICISS report. It concludes that there are significant potential benefits to adopting a 'human rights lens' if states are willing to fulfil their pillars one and two responsibilities.
\end{abstract}

Keywords: Atrocity Crimes; Human Rights; International Criminal Law; Responsibility to Protect.

\section{Article:}

The consensus built around the Responsibility to Protect is as strong as it is undeniable. The vast majority of UN member states are in agreement with the 
core principles of R2P and significant resources have been mobilized at national, regional and international levels to elaborate on what these principles mean in practice for the most vulnerable civilians at risk of mass atrocity crimes. ${ }^{1}$

The brutality of today's armed conflicts and the utter lack of respect for the fundamental rules of international humanitarian law threaten to unravel 150 years of achievements, and risks leading to an era of war without limits. Flouting the most basic rules governing the conduct of war has become contagious, creating further opportunities to reinterpret and blur their application. The failure to demand and promote respect for our shared norms, to enforce the law, and to support or cooperate with national and international monitoring and accountability mechanisms all contribute to the erosion of the rule of law and bring about profound human suffering. ${ }^{2}$

You cannot believe this is happening, and the fear and the horror of the people in those circumstances is hardly possible in the 21 st century... How could we still be doing this? There are rules. ${ }^{3}$

\footnotetext{
${ }^{1}$ Global Centre for the Responsibility to Protect, 'Summary of the Report of the UN Secretary General: Mobilizing Collective Action: The Next Decade for the Responsibility to Protect', 1 August 2016, http://www.globalr2p.org/media/files/2016-august-summary-of-un-secretary-general-report-onr2p.pdf, accessed 10 December 2016, p. 1.

2 'Uphold the Norms that Safeguard Humanity' High-Level Leaders' Roundtable, 'Core Responsibility Two of the Agenda for Humanity', 22-24 May 2016 https://consultations.worldhumanitariansummit.org/bitcache/5ecfea77f1ae20834595de17b4df128ab84 e526c?vid=571406\&disposition=inline\&op=view, accessed 10 December 2016, p. 2.

${ }^{3}$ Zeid Ra'ad al Hussein, UN High Commissioner for Human Rights, News Briefing on Situation in Syria, reported in Tom Miles, 'U.N.'s Zeid cool on Syrian opposition plan to bypass Russian veto', 5
} 
The Responsibility to Protect (R2P) doctrine has failed to protect vulnerable populations in many conflict situations in the eleven years since states committed to its principles at the 2005 World Summit. ${ }^{4}$ This, in itself, is not particularly remarkable - after all, norms take time to cascade, and there are various markers which suggest a cascade of sorts is taking place.

However, atrocity crimes - the very acts which R2P is focused upon protecting populations from - have increased in frequency and scale recently. The United Nations Secretary General (UNSG) acknowledges in his latest report on R2P that 'in 2014 the number of deaths caused by armed conflict and atrocity crimes exceeded 100,000 — its highest level since 1994 _ driven in large measure by the increased targeting of civilians' ${ }^{5}$ In 2016 we saw an unprecedented four humanitarian emergencies, in Syria, Iraq, Yemen and South Sudan. A great deal of work has been done to try to improve the purchase of R2P upon atrocity crimes. This article takes a different path, arguing that, as the benefits that were expected to accrue from the narrowing down of a relatively expansive initial conception of the R2P have failed to materialise, the focus on atrocity crimes should be rethought. I argue that R2P advocates should expand their gaze to the full field of human rights protection to maximise the potential impact of the doctrine. The first section below discusses the current state of the doctrine and outlines its position in the global normative architecture. The following section examines the benefits and costs of the atrocity crimes focus. The article then examines what it would mean

October 2016, available at: http://www.reuters.com/article/us-mideast-crisis-syria-zeididUSKCN12C1AZ, accessed 10 December 2016.

${ }^{4}$ I would like to thank Alistair Brunning for his generous assistance in gathering information about UN policies and practices for this article.

${ }^{5}$ Ban Ki Moon, Mobilizing Collective Action: The Next Decade of The Responsibility To Protect, A/70/999, 22 July 2016, p. 3. Research cited is Erik Melander, 'Organized Violence in the World 2015: an Assessment by the Uppsala Conflict Data Program', (Uppsala: Uppsala Conflict Data Program, 2015); available from www.pcr.uu.se/data/overview_ucdp_data/, accessed 1 December 2016. 
to expand the scope of $\mathrm{R} 2 \mathrm{P}$ to be more clearly a part of the global human rights project, and what the benefits of doing so might be. It concludes by acknowledging the ethical and political complexity of deciding how best to 'position' R2P within the global normative sphere, but suggests that the reinvigoration of R2P's initial human rights focus could have significant advantages over the current atrocity focus.

\section{R2P in Contemporary Global Politics}

Pace the claims of advocacy organisations such as the Global Centre for the Responsibility to Protect, R2P is in crisis. ${ }^{6}$ It would be erroneous to make one situation the standard against which R2P is judged, but even a cursory analysis of the role of the international community in the conflict in Syria suggests the doctrine should be dismissed as, at best, rhetoric. Half a million people have died in Syria over 5 years and millions have been displaced. ${ }^{7}$ As the first draft of this article was being completed, an urban population in Eastern Aleppo was suffering under the most ruthless bombardment, including hospitals and schools being targeted and double tap strikes being used to kill first responders. The great powers - those with the lastresort responsibility to protect via United Nations Security Council (UNSC) action - either acted to support the slaughter, or claimed powerlessness to stop it, while doing what they could to avoid offering refuge to anyone who managed to escape. The scale of atrocity

\footnotetext{
${ }^{6}$ Simon Adams, 'Statement of the Global Centre for the Responsibility to Protect at the 2016 UN General Assembly Informal Interactive Dialogue on the Responsibility to Protect' 6 September 2016, http://www.globalr2p.org/media/files/2016-september-gcr2p-r2p-interactive-dialogue-statement-2.pdf, accessed 1 December 2016. For further discussion of the problems faced by R2P, see Aidan Hehir 'From Human Security to the Responsibility To Protect: The Co-Option of Dissent?', Michigan State International Law Review 23/3: 675-99 (2015) and Kirsten Ainley, 'The Responsibility to Protect and the International Criminal Court: Counteracting the Crisis', International Affairs 91/1: 37-54 (2015). ${ }^{7}$ Syrian Center for Policy Research, 'Confronting Fragmentation', 11 February 2016, http://scprsyria.org/publications/confronting-fragmentation/, accessed 1 December 2016.
} 
commission in Syria is near impossible to comprehend, and even when the killing has stopped, the maiming of Syrian society and destruction of its economy will take decades to overcome. The failure of the international community, principally the UNSC Permanent 5 (P5), to do anything meaningful to alleviate this crisis, despite making grand statements about the R2P, may mark the beginning of the end of anyone taking such statements seriously.

But the failure of R2P to motivate state action in the face of one of the most complex and devastating wars of the last 50 years isn't necessarily the failure of the doctrine. Rather, it is the rest of the catalogue of failures of $\mathrm{R} 2 \mathrm{P}$ which, added to Syria, make the case that the doctrine should be re-evaluated. There a large number of other situations upon which R2P would have been expected to have some purchase, for instance, Sri Lanka, Darfur, the Democratic Republic of Congo, Bahrain, Nigeria, Iraq, South Sudan and Yemen. ${ }^{8}$ In the face of crises in these states, third party states and international organisations did or are doing very

\footnotetext{
8 'Report of the UN Secretary General's Panel of Experts on Accountability in Sri Lanka', 31 March 2011, http://www.un.org/News/dh/infocus/Sri_Lanka/POE_Report_Full.pdf, accessed 1 December 2016; Alex de Waal, 'Darfur and the Failure of the Responsibility to Protect' International Affairs 83/6: 1039-54 (2007); Herbert Weiss, 'The Democratic Republic of the Congo', in Richard H. Cooper \& Juliette Voinov Kohler (eds.) Responsibility To Protect: The Global Moral Compact For The 21st Century (London: Palgrave Macmillan, 2009); Aidan Hehir 'Bahrain: an R2P Blind Spot?' The
} International Journal of Human Rights 19/8: 1129-47 (2015); United Nations Security Council, 'Statement by the President of the Security Council', 13 May 2016, S/PRST/2016/7; Human Rights Council 'They Came to Destroy? : ISIS Crimes against the Yazidis', 15 June 2016, A/HRC/32/CRP.2, http://www.ohchr.org/Documents/HRBodies/HRCouncil/CoISyria/A_HRC_32_CRP.2_en.pdf, accessed 1 December 2016; UN News Centre, International Community has Obligation to Prevent 'Ethnic Cleansing' in South Sudan - UN Rights Experts', 1 December 2016, http://www.un.org/apps/news/story.asp?NewsID=55693\#.WEM5bI tmk, accessed 1 December 2016; United Nations High Commissioner for Human Rights, 'Situation of Human Rights in Yemen', 4 August 2016, available via http://www.ohchr.org/EN/Countries/MENARegion/Pages/YemenReport.aspx, accessed 1 December 2016. 
little to offer genuine protection to populations under threat. In a sign of its waning commitment to the principles of $\mathrm{R} 2 \mathrm{P}$, the UNSC chose, in the face of escalating crises, to cease to receive horizon-scanning briefings for potential crisis situations. ${ }^{9}$ More broadly, most states failed, at the 2016 World Humanitarian Summit, to commit to conflict prevention and resolution, despite the recognition of the summit that 'prevention and conflict resolution remain a laudable ambition rather than a concrete and operational activity that is adequately equipped, financed and championed. ${ }^{10}$ This is despite the establishment at the UN in 2008 of the position of the Special Adviser on the Responsibility to Protect, whose office has worked to propagate the $\mathrm{R} 2 \mathrm{P}$ norm through states and international institutions, and despite extensive advocacy for state action by well-funded R2P-focused NGOs such as the Global Centre for the Responsibility to Protect and the International Coalition for the Responsibility to Protect.

This is not to say that examples of possible R2P successes cannot be found. However, these successes are often claimed by proponents of a range of international norms, with no way to know whether the action was due to R2P. R2P language has featured in 50 UNSC resolutions, and civilian protection is now central to UN peacekeeping operations, but the 'Protection of Civilians in Armed Conflict' (PoC) became a separate theme for the UNSC in 1999, so it is unclear whether the focus of the Council on (talking about) protection is a success for PoC or

\footnotetext{
${ }^{9}$ Security Council Report, 'Horizon-Scanning Briefings', 1 November 2016, http://www.securitycouncilreport.org/un-security-council-working-methods/atf/cf/\%7B65BFCF9B6D27-4E9C-8CD3-CF6E4FF96FF9\%7D/working methods horizon scanning.pdf, accessed 1 December 2016.

${ }^{10}$ UN Secretary General, 'Outcome of the World Humanitarian Summit', 23 August 2016, A/71/353, https://www.worldhumanitariansummit.org/sites/default/files/media/A-71-353\%20\%20SG\%20Report\%20on\%20the\%20Outcome\%20of\%20the\%20WHS.pdf, accessed 1 December 2016.
} 
$\mathrm{R} 2 \mathrm{P} .{ }^{11}$ Claims are also made that $\mathrm{R} 2 \mathrm{P}$ motivated action recently in the Central African Republic and South Sudan, though these are also claimed as successes for the UN's Human Rights Up Front initiative. ${ }^{12}$ They are also far from widely agreed to be successes. ${ }^{13}$ And there are few signs that the situation will improve. The argument is sometimes made that human

\footnotetext{
${ }^{11}$ On the UNSC negotiating 'agreed language' on R2P, see Jason Ralph and Jess Gifkins, 'The Purpose of United Nations Security Council Practice: Contesting Competence Claims in the Normative Context Created by the Responsibility to Protect', European Journal of International Relations (forthcoming 2016). On the UNSC and PoC, see Security Council Report 'Protection of Civilians in Armed Conflict, 20 December 2013, http://www.securitycouncilreport.org/atf/cf/\%7B65BFCF9B-6D27-4E9C-8CD3-
} CF6E4FF96FF9\%7D/cross cutting report 3 protection of civilians 2013.pdf, accessed 1 December 2016, and, on R2P and PoC in practice, Paul D. Williams, 'The R2P, Protection of Civilians, and UN Peacekeeping Operations' in Alex J. Bellamy and Tim Dunne (eds.), The Oxford Handbook of the Responsibility to Protect (Oxford: Oxford University Press, 2016). Breakey notes an increased suspicion about $\mathrm{PoC}$ within UNSC discussions, manifesting as pushback against PoC commitments being included in peacekeeping mandates, and suggests that this was due to R2P action in Libya and Cote d'Ivoire: Hugh Breakey, 'R2P and POC in the UN Security Council', 6 March 2013, http://hughbreakey.blogspot.co.uk/2013/03/r2p-and-poc-in-un-security-council.html, accessed 1 December 2016.

${ }^{12}$ Andrew Gilmour, 'The Future of Human Rights: A View from the United Nations', Ethics and International Affairs, 28/2: 239-50 (2014); International Coalition for the Responsibility to Protect (ICRtoP), 'Rights Up Front and Civilian Protection: An Uneven First Year', 25 November 2014, https://icrtopblog.org/2014/11/25/rights-up-front-and-civilian-protection-an-uneven-first-year/, accessed 1 December 2016.

${ }^{13}$ On CAR, see Evan Cinq-Mars, 'Too Little, Too Late: Failing to Prevent Atrocities in the Central African Republic', Global Centre for the Responsibility to Protect Occasional Paper Series No. 7, September 2015, available at http://www.globalr2p.org/media/files/occasionalpaper_car_final.pdf, accessed 1 December 2016. On South Sudan, see Lars Waldorf, ‘Inhumanity's Law: Crimes Against Humanity, RtoP and South Sudan', International Politics 53: 49-66 (2016). See also reports of serious failures of UN peacekeeping, for instance: Jason Burke, 'Sudanese and Aid Workers Raped and Murdered and UN peacekeepers Didn't Help, 6 October 2016, https://www.theguardian.com/world/2016/oct/06/un-peacekeepers-refused-to-help-south-sudan-rebelsraped-aid-workers-report, accessed 1 December 2016. Murdie, in this volume, provides useful criteria for judging success. 
rights norms took 50 years to transform global politics, so R2P is being judged too early. But there are two important points to note here - firstly, human rights were being fought for and about during that time: refined, campaigned around and codified into treaties and agreements. Secondly, despite significant efforts to further embed R2P principles in UNSC decisionmaking, for instance through veto restraint, the R2P norm looks unlikely to cascade or 'ripen' much further in its current form. ${ }^{14}$ There is no underlying consensus about what it means, and no willingness on the part of states to become legally bound to exercise a responsibility to protect foreign populations. ${ }^{15}$ In addition, as the distribution of power in the international system shifts, rising states are unlikely to be passive norm-takers, particularly if those norms are seen to disproportionately benefit Western powers. ${ }^{16}$ There is therefore some justification for a more substantial re-conceptualisation of the doctrine, which is undertaken below by returning to the original radical potential of $\mathrm{R} 2 \mathrm{P}$, as conceptualised in the International Commission on State Sovereignty (ICISS) report, and linking the doctrine much more explicitly to the promotion of human rights than the protection of civilians.

\footnotetext{
${ }^{14}$ As of 2016, more than 100 states have signed up to the ATC Code of Conduct and/ or a French/ Mexican proposal on restraining the use of the UNSC veto. See Security Council Report, 'The Veto', 7 December 2016, http://www.securitycouncilreport.org/un-security-council-working-methods/theveto.php accessed 10 December 2016. However, only France and the UK, of the UNSC P5, support the Code of Conduct, and only France supports the restraint on the veto. See http://www.responsibilitytoprotect.org/Veto\%20map\%20(Conflict\%20Copy).pdf for a full list of
} states who supported the two proposals at 11 January 2016. The French/ Mexican statement is available at http://www.franceonu.org/IMG/pdf/2015_08_07_veto_political_declaration_en.pdf, accessed 1 December 2016 and the ATC Code of Conduct at http://www.centerforunreform.org/sites/default/files/Final\%202015-0901\%20SC\%20Code\%20of\%20Conduct\%20Atrocity.pdf, accessed 1 December 2016.

${ }^{15}$ Theresa Reinold, 'The Responsibility to Protect - Much Ado about Nothing?', Review of International Studies, 36/1: 55-78 (2010).

${ }^{16}$ Edward Newman, 'R2P: Implications for World Order', Global Responsibility to Protect, 5/3: 23559 (2013). 
R2P sits in an incredibly complex normative landscape in global politics. Normative agendas within international bodies and international legal regimes which R2P overlaps or connects to include: international humanitarian law (IHL); international criminal law (ICL); genocide/ atrocity prevention; conflict prevention; Protection of Civilians (which focuses on situations of armed conflict); Women, Peace and Security; refugee protection; international human rights law (IHRL); human rights promotion; Human Rights Up Front; and human security. ${ }^{17}$ At present, R2P is most closely associated with legal regimes around the laws of war and the most egregious violations of human rights (as codified in ICL, in particular the Rome Statute) and normative regimes with relatively long histories in the UN around genocide prevention and the protection of civilians during conflict. It is focused upon protecting populations from four core crimes: genocide, crimes against humanity, war crimes and ethnic cleansing. The sections below explore the implications of moving the focus along the normative spectrum to more fully encompass the protection and promotion of human rights within states and in international organisations. But first, the benefits and costs of the current instantiation of R2P are examined.

\section{The Atrocity Crime Focus}

\footnotetext{
${ }^{17}$ Alex J. Bellamy, 'Conflict Prevention and the Responsibility to Protect', Global Governance: A Review of Multilateralism and International Organizations, 14/2: 135-56 (2008); Hugh Breakey, 'Protection Norms and Human Rights: A Rights-Based Analysis of the Responsibility to Protect and the Protection of Civilians in Armed Conflict', Global Responsibility to Protect, 4/3: 309-333 (2012); Sara E Davies, Sarah Teitt and Zim Nwokora 'Bridging the Gap: Early Warning, Gender and the Responsibility to Protect, Cooperation and Conflict 50/2: 228-49 (2015); David Jason Karp, 'The Responsibility to Protect Human Rights and the R2P: Prospective and Retrospective Responsibility' Global Responsibility to Protect, 7: 142-66 (2015).
} 
$\mathrm{R} 2 \mathrm{P}$ was not designed in its original instantiation as a doctrine focused on breaches of international criminal law and IHL. The second principle of R2P, according to the ICISS report, demands that states (and the international community when states fail) exercise a responsibility to protect civilians from a wide range of serious harms, not just from crimes: '[w] here a population is suffering serious harm, as a result of internal war, insurgency, repression or state failure, and the state in question is unwilling or unable to halt or avert it, the principle of non-intervention yields to the international responsibility to protect. ${ }^{, 18}$ The report goes on to offer a long list of circumstances in which intervention under what would become pillar three might be justified:

those actions defined by the framework of the 1948 Genocide Convention that involve large scale threatened or actual loss of life; the threat or occurrence of large scale loss of life...; different manifestations of "ethnic cleansing,"...; the systematic physical removal of members of a particular group from a particular geographical area; acts of terror designed to force people to flee; and the systematic rape for political purposes of women of a particular group...; those crimes against humanity and violations of the laws of war ... which involve large scale killing or ethnic cleansing; situations of state collapse and the resultant exposure of the population to mass starvation and/or civil war; and overwhelming natural or environmental catastrophes, where the state concerned is either unwilling or unable to cope, or call for assistance, and significant loss of life is occurring or threatened. ${ }^{19}$

\footnotetext{
${ }^{18}$ International Commission on State Sovereignty (ICISS), The Responsibility to Protect (Ottawa: IDRC, 2001), p. XI.

${ }^{19}$ ICISS, The Responsibility to Protect, p.33.
} 
However, diplomatic negotiations between states to reach agreement at the 2005 World Summit led to a significant narrowing of the scope of R2P, to focus only on atrocity crimes. This narrowing can be seen in paragraph 138 of the World Summit Outcome Document: '[e]ach individual State has the responsibility to protect its populations from genocide, war crimes, ethnic cleansing and crimes against humanity...” and paragraph 139: ‘[t]he international community, through the United Nations, also has the responsibility to use appropriate diplomatic, humanitarian and other peaceful means, in accordance with Chapters VI and VIII of the Charter, to help to protect populations from genocide, war crimes, ethnic cleansing and crimes against humanity... ${ }^{20}$ The reasons for this narrowing of focus because states already had obligations under international law to protect their populations from the four crimes, and because non-Western states wanted a reassurance that external intervention would be tolerated only in very limited circumstances - have to some extent been forgotten. ${ }^{21} \mathrm{R} 2 \mathrm{P}$ advocates instead tend to commend the 'atrocity lens', claiming that because the World Summit version of the doctrine builds on existing state consensus, it allows for a 'deep' application of R2P principles to situations of the very worst human suffering. ${ }^{22}$ However, as outlined above, while the application of R2P is certainly narrow, it has not been deep. Atrocity crimes are increasing, and even when the international community does

\footnotetext{
20 '2005 World Summit Outcome', UNGA Res. 60/1, 16 September 2005.

${ }^{21}$ Margaret M. Deguzman, 'When Are International Crimes Just Cause for War?' Virginia Journal of International Law 55/1: 73-116 (2014); Jennifer M. Welsh, 'Norm Contestation and the Responsibility to Protect', Global Responsibility to Protect 5/4: 365-96 (2013).

${ }^{22}$ Jennifer M. Welsh, "The "Narrow but Deep Approach" to Implementing the Responsibility to Protect: Reassessing the Focus on International Crimes', in S. P. Rosenberg, T. Galis and A. Zucker (eds.) Reconstructing Atrocity Prevention (Cambridge: Cambridge University Press, 2015); Alex J. Bellamy ‘The Responsibility to Protect-Five Years On' Ethics \& International Affairs, 24/2: 143-69 (2010).
} 
respond, as it did in Libya, R2P principles of protection did not run deep enough for intervenors to support the Libyan population in the aftermath of the NATO strikes. ${ }^{23}$

Some R2P advocates have responded to this situation by suggesting that the focus of R2P should be narrowed even further. ${ }^{24}$ However, the focus on atrocity crimes is problematic in principle as well as in practice, in particular because of the way it positions $\mathrm{R} 2 \mathrm{P}$ in relation to conflict. This is evident in three ways. Firstly, the atrocity focus fetishizes the distinction between war and war crimes, rendering invisible harm which takes place within the laws of war. War is an inherently destructive activity, whether or not rules are followed, and the following of the rules might even prolong conflict. The US is currently embroiled in the longest war in its history - an 'endless, clean war' - which is estimated to have cost $1.3 \mathrm{~m}$ million lives in Iraq, Afghanistan and Pakistan since $2001 .^{25}$ Atrocity-focused R2P, like IHL and Just War criteria, is in some ways an enabler of war - it gives the false impression that war can be humanised and the worst excesses of it prevented. ${ }^{26}$ Related to this is the tendency of the referent object of protection within R2P, 'populations', to be operationalised as

\footnotetext{
${ }^{23}$ Outi Keranen 'What Happened to the Responsibility to Rebuild?', Global Governance: A Review of Multilateralism and International Organizations, 22/3: 331-48 (2016).

${ }^{24}$ Auriane Botte, 'Redefining the Responsibility to Protect Concept as a Response to International Crimes', The International Journal of Human Rights, 19/8: 1029-43 (2015).

${ }^{25}$ Samuel Moyn, 'Civil Liberties and Endless War', Dissent 62/4: 57-61 (2015); International Physicians for the Prevention of Nuclear War, Physicians for Social Responsibility and Physicians for Global Survival, 'Body Count: Casualty Figures after 10 Years of the 'War on Terror', March 2015, http://www.psr.org/assets/pdfs/body-count.pdf, accessed 1 December 2016.

${ }^{26}$ Laura Sjoberg, Gender, Justice and the Wars in Iraq: a Feminist Reformulation of Just War Theory (Lanham: Lexington Books, 2006); Samuel Moyn, Toward a History of Clean and Endless War, October 9 2015, https://www.justsecurity.org/26697/sanitizing-war-endlessness/, accessed 1
} December 2016. 
'civilians', as seen in the PoC agenda. This has the effect of moving those who can plausibly be labelled as combatants largely outside the sphere of R2P concern. ${ }^{27}$

Secondly, the narrow focus of R2P leads to a simplistic view of actors in atrocity situations as perpetrators (who should be stopped and prosecuted) and victims (who should be pitied and protected). Such a view is inaccurate, as the lines between good and evil, particularly if atrocity is taking place within conflict, are usually far more blurred, and atrocity crimes are facilitated by context as much or more than by the character of individuals. ${ }^{28}$ The range of actors involved in atrocity crimes also extends beyond victim and perpetrator to include the enablers of atrocity such as arms sellers and states who prop up illegitimate regimes. The simplistic view of perpetrators and victims is an impediment both to ending conflict (which often involves negotiation with those who a crimes-perspective would suggest should be arrested) and to seeing the population under threat as rights-bearing agents rather than vulnerable objects. $^{29}$

Finally, the atrocity-crimes focus tends to assume that atrocities take place in the context of conflict, therefore directing attention away from i) the non-conflict situations in which atrocity crimes take place, and ii) the many contexts in which large scale human suffering exists which is not brought about by the commission of atrocities, but is nonetheless susceptible to reduction via concerted political action, for instance the harms resulting from

\footnotetext{
${ }^{27}$ Vesselin Popovski, 'Siblings, but not Twins: PoC and R2P', United Nations University, 1 November 2011, http://unu.edu/ publications/articles/siblings-but-nottwins-poc-and-r2p.html, accessed 1 December 2016.

${ }^{28}$ Welsh, 'The "Narrow but Deep Approach" to Implementing the Responsibility to Protect'; Kirsten Ainley, 'Individual Agency and Responsibility for Atrocity', in Renee Jeffery (ed.) Confronting Evil in International Relations: Ethical Responses to Problems of Moral Agency (London: Palgrave, 2008). ${ }^{29}$ Karp, 'The Responsibility to Protect Human Rights and the R2P'.
} 
oppression, famine/ starvation, slavery, disease, human trafficking, arms trafficking and refugee flows. ${ }^{30}$ Starr notes, in the context of international criminal law, that 'for the perpetrators of massive systemic crimes committed during peacetime—such as the world's worst tyrants, kleptocrats, and profiteers of state-enabled sexual slavery-impunity remains the order of the day. ${ }^{31} \mathrm{R} 2 \mathrm{P}$, as it is now tied so closely to ICL, gives us no purchase upon such harms. The former Special Advisor on R2P has recognised that the nature of violence is changing and that crimes occur outside conflict: 'our office is concerned about any form of massive violations of human rights as potential triggers for mass atrocity crimes', but noted that such situations are unlikely to lead to pillar three actions. In terms of UNSC action, the discourse around $\mathrm{R} 2 \mathrm{P}$ remains centred on conflict, atrocity in conflict, and, to a lesser extent, conflict prevention. $^{32}$

\section{R2P and Human Rights}

The remainder of the article works through what it might mean to take R2P back to its ICISS roots and align it much more closely with the full range of human rights norms, laws and institutions rather than just the subset of breaches of human rights which atrocity crimes represent. The assumptions which underlie this position are, firstly, that as R2P does not offer

\footnotetext{
${ }^{30}$ Around two thirds of atrocities take place in the context of conflict, although that proportion has increased significantly since 1980: Alex J. Bellamy, 'Mass Atrocities and Armed Conflict: Links, Distinctions, and Implications for the Responsibility to Protect', The Stanley Foundation, 2011, http://www.stanleyfoundation.org/publications/pab/BellamyPAB22011.pdf, accessed 1 December 2016.

${ }^{31}$ Sonja Starr, 'Extraordinary Justice at Ordinary Times: International Justice Beyond Crisis Situations', Northwestern University Law Review, 101/3: 1257-314 (2007).

${ }^{32}$ Adam Lupel, 'The Responsibility to Protect Principle is not the Problem: Interview with Jennifer Welsh', 11 December 2013, https://theglobalobservatory.org/2013/12/the-responsibility-to-protectprinciple-is-not-the-problem-interview-with-jennifer-walsh/, accessed 1 December 2016.
} 
adequate protection under pillar three (due to a lack of political will to intervene when states fail in their pillar one responsibilities), then focus should turn to pillars one and two much more explicitly. ${ }^{33}$ It is worth emphasising here that the argument here is not an attempt to make pillar three interventions more likely when conditions are met to justify them - an expansion of R2P's focus would not solve the problem of a lack of political will on behalf of states to follow through on their pillar three obligations. Rather the expanded focus is argued to circumvent the lack of political will (at least to some extent) by reducing the incidence of atrocity crimes.

Secondly, the argument is premised upon a link between atrocity crimes and human rights violations, with the former understood as subset of the latter. As the current UN High Commissioner for Human Rights (UNHCHR), Zeid Ra'ad al Hussein, has observed when recounting the history of mass atrocity crimes: 'None of these atrocities crimes were unleashed without warning. They built up over years - and sometimes decades - of human rights grievances. Among them we must count deficient or corrupt governance and judicial institutions; discrimination and exclusion of minorities; inequities in development; exploitation and denial of economic and social rights; and repression of civil society and public freedoms. ${ }^{34}$ The former Special Advisor on R2P notes that if states fail to protect human rights by: 'establishing legitimate and accountable national institutions; by eliminating corruption; by managing diversity constructively; and by supporting a strong and diverse civil society and a pluralistic media', they can create 'an environment conducive to atrocity

\footnotetext{
${ }^{33}$ This argument is made at more length in Ainley, 'The Responsibility to Protect and the International Criminal Court'.

${ }^{34}$ Zeid Ra'ad Al Hussein, 'Preventing and Addressing Violence and Atrocity Crimes Targeted Against Minorities', 25 November 2014, Seventh Session of the United Nations Forum on Minority Issues, http://www.ohchr.org/EN/NewsEvents/Pages/DisplayNews.aspx?NewsID=15344\&LangID=E\#sthash.
} GdA2U8uU.dpuf, accessed 4 December 2016. 
crimes'. ${ }^{35}$ Claims that atrocity crimes are likely to be less frequent as human rights protections increase are based upon literature suggesting that small episodes of violence escalate to larger ones (which create the conditions for the majority of atrocities), in states with high levels of inequality; high levels of poverty; weak, corrupt or brutal governments; and governments dominated by the corrupt politics of natural resources. ${ }^{36}$

Thirdly, it is assumed that the documentation of evidence of serious harms by credible bodies is valuable even if it is not likely to lead to pillar three action, as it establishes a public record and may be used in later judicial proceedings. As noted above, focus on human rights within $\mathrm{R} 2 \mathrm{P}$ is unlikely to make intervention more likely when atrocity crimes are being committed. However, it could i) reduce the likelihood of atrocity crimes (and other large-scale human rights violations) being committed in the first place, and ii) increase the chance of some relatively meaningful response to serious harms which do occur, through investigation and the documentation of evidence.

It might at first seem strange to suggest that the focus of R2P should be broadened out to make it more explicitly a human rights doctrine. After all, R2P advocates talk about human rights frequently, some even seeing R2P as 'the correct interpretation of the very meaning of the responsibility to protect human rights of specifically international actors in the world

\footnotetext{
${ }^{35}$ Lupel, 'The Responsibility to Protect Principle is not the Problem'.

${ }^{36}$ Lars-Erik Cederman, Nils B. Weidmann and Kristian Skrede Gleditsch, 'Horizontal Inequalities and Ethno-Nationalist Civil War: A Global Comparison', American Political Science Review, 105/3: 47895 (2011); James D. Fearon and David Laitin, 'Ethnicity, Insurgency, and Civil War', American Political Science Review, 97/1: 75-90 (2003); Paul Collier, The Bottom Billion. (Oxford: Oxford University Press, 2004); Philippe Le Billon, Wars of Plunder (London: Hurst \& Co, 2012); Michael Ross, 'What Do We Know About Natural Resources and Civil War?' Journal of Peace Research 41/3: $337-56$ (2004).
} 
today,. ${ }^{37}$ Certainly the human rights frame was central to the ICISS report: 'Human rights have now become a mainstream part of international law, and respect for human rights a central subject and responsibility of international relations ... Even though in some cases imperfectly implemented, [human rights] agreements and mechanisms [including the Universal Declaration of Human Rights and the two 1966 Covenants relating to civil, political, social, economic and cultural rights alongside IHL and ICL] have significantly changed expectations at all levels about what is and what is not acceptable conduct by states and other actors. ${ }^{38}$ The report also sees the protection of human rights, broadly conceived, as necessary to the fulfilment of the responsibility to prevent: 'Efforts to ensure accountability and good governance, protect human rights, promote social and economic development and ensure a fair distribution of resources point toward the necessary means. ${ }^{39}$ And the aim of interventions ('human protection operations') is defined as 'enforc[ing] compliance with human rights and the rule of law as quickly and as comprehensively as possible' ${ }^{40}$ However, as noted earlier, the effort to narrow the scope of R2P at the World Summit means that the doctrine as it is formally understood (through the 2005 World Summit Outcome Document) does not include a broader conception of human rights protection or promotion.

What would it mean to conceptualise $\mathrm{R} 2 \mathrm{P}$, once again, as a doctrine which necessitated a more holistic commitment to human rights? It would mean incorporating into the advocacy around R2P: 'the responsibility of states (and, ideally, also corporations and other public bodies) to proactively ensure that the structural conditions of human rights protection are systematically institutionalized' ${ }^{41}$ That is, it would involve moving away from seeing R2P as

\footnotetext{
37 Karp, 'The Responsibility to Protect Human Rights and the R2P', p.148.

38 ICISS, The Responsibility to Protect, Paragraph 1.25, p. 6.

${ }^{39}$ ICISS, The Responsibility to Protect, Paragraph 3.2, p. 19.

${ }^{40}$ ICISS, The Responsibility to Protect, Paragraph 7.51, p. 67.

${ }^{41}$ Karp, 'The Responsibility to Protect Human Rights and the R2P', p143.
} 
principally about the protection of the vulnerable from atrocity, towards conceptualising the norm as incorporating a much more radical call for structural change to empower populations through the robust promotion of rights. In practice, this would involve $\mathrm{R} 2 \mathrm{P}$ advocates working in solidarity with rights-focused NGOs and international mechanisms to hold states responsible for a wide range of human rights protections; and campaigning both for the extension of human rights protections (rather than just for atrocity prevention) and for increased funding for human rights work. It would mean R2P advocates working to bring 'rights up front' (to use the current UN terminology) in both the rhetoric and practice of R2P work, particularly around pillars one and two. It would not involve jettisoning a concern with atrocity crimes, but rather challenging (via advocacy) the narrow conceptualisation of R2P within the World Summit Document as concerned only with atrocity crimes.

A particularly promising way to extend the $\mathrm{R} 2 \mathrm{P}$ agenda is for $\mathrm{R} 2 \mathrm{P}$ advocates, in the Special Advisor's Office, states, international organisations and NGOs, to work more closely with institutions charged with the protection and promotion of human rights. Among the most powerful of these are the UN Office of the High Commission of Human Rights (OHCHR), headed by the UNHCHR, and the Human Rights Council (HRC). The UNHCHR has outlined the relationship between $\mathrm{R} 2 \mathrm{P}$ and human rights institutions as follows:

[p]revention of human rights violations is at the core of the responsibility to protect. If we intervene only after a situation reaches the point of crisis, when the horror of atrocity crimes has already begun, then, we have already failed to protect the most vulnerable ... The Human Rights Council plays a key role in implementing the Responsibility to Protect, even if its work is not often framed in these terms. The Council's special procedure mandate holders have demonstrated that, like the staff of my Office, they have the capacity to detect 
looming crises and give early warning. Their recommendations, together with those of the treaty bodies and my Office, can address human rights-related risk factors that are also identified in the U.N. Framework of Analysis for Atrocity Crimes. ${ }^{42}$

However, despite this recognition of the links between $\mathrm{R} 2 \mathrm{P}$ and human rights, there has been little development of the relationship, or moves to formalise R2P work within OHCHR. ${ }^{43}$ There are three mechanisms within the OHCHR and the HRC which R2P advocates could make more use of. The first are the 'special procedures', which are the thematic or countryspecific special rapporteurs, special representatives, independent experts and working groups established to monitor and publicly report on thematic issues or human rights situations in specific countries ${ }^{44}$ There are a wide range of thematic issues, on many aspects of human rights work (for instance special rapporteurs on extrajudicial, summary or arbitrary executions; the human rights of internally displaced persons; extreme poverty; contemporary slavery; and violence against women). Integrating an R2P perspective into the work of these rapporteurs - including pressing for mandates to be extended to include interrogation of the links between human rights violations in the areas covered by the mandates and serious harms to populations more broadly (including atrocity crimes) - would help to join up the UN's information sources. As the UNHCHR notes (above) these mandate holders are also in good

\footnotetext{
42 'High Commissioner's Statement to High-Level Event on Implementing R2P in the Geneva Context', 19 November 2015, http://www.ohchr.org/EN/NewsEvents/Pages/DisplayNews.aspx?NewsID=16776\&LangID=E\#sthash. wUzuHj4U.dpuf, accessed 1 December 2016.

${ }^{43}$ Ekkehard Strauss, 'UN Human Rights Council and High Commissioner for Human Rights' in Bellamy and Dunne (eds.), The Oxford Handbook of the Responsibility to Protect.

${ }^{44}$ OHCHR, 'Special Procedures of the Human Rights Council', http://www.ohchr.org/EN/HRBodies/SP/Pages/Welcomepage.aspx, accessed 4 December 2016.
} 
positions to contribute to 'early warning' and pillar one prevention efforts, as they have privileged access to information from within states and can undertake fact-finding missions, issue reports (either privately or publically to name and shame), send communications to states to bring possible human rights violations to their attention and identify trends in human rights threats. They can also assist in a broader prevention agenda by developing international human rights standards rather than simply responding to breaches of existing IHRL. Special Procedures report annually to the Human Rights Council and most also report to the General Assembly, giving states significant opportunities to assess trends in human rights breaches and observance, and to respond accordingly.

The second mechanism is the Universal Periodic Review (UPR), run through the HRC. The HRC is mandated to 'undertake a universal periodic review, based on objective and reliable information, of the fulfilment by each State of its human rights obligations and commitments in a manner which ensures universality of coverage and equal treatment with respect to all States ${ }^{45}$ This process offers significant scope for R2P actors to pressure states to evaluate their pillar one actions (in terms of atrocity prevention as well as the protection of human rights more broadly) during the UPR process, and for NGOs, states and international organisations to consider how they can exercise their pillar two responsibilities with respect to states under UPR, in particular via capacity building to enhance rights protections and assistance with the creation of mechanisms for societal and government/society dialogue to pre-empt conflict. ${ }^{46}$ Ideally, UPR would also be used to document and challenge the poverty and unequal resource distribution (to the extent that these are indicators of a failure to uphold economic rights) that are often root causes of conflict. The Reviews only take place every

\footnotetext{
${ }^{45}$ OHCHR, 'Basic Facts about the UPR', http://www.ohchr.org/EN/HRBodies/UPR/Pages/BasicFacts.aspx, accessed 4 December 2016
} 
four years, but even so they are a valuable opportunity for R2P advocates to contribute to review processes, as the reviews are reported to, and discussed within, the HRC. ${ }^{47}$ If it is acknowledged that human rights breaches usually precede atrocity crimes, UPR is valuable as it offers a more holistic view of the full human rights records of states than an atrocity lens. This could contribute to atrocity prevention both via increased pressure to conform to human rights standards from $\mathrm{R} 2 \mathrm{P}$ advocates, and to an earlier 'early warning' than current atrocityfocused systems can provide.

The final OHCHR/ HRC mechanisms R2P advocates could use to promote a broader protection agenda are commissions of inquiry and fact-finding missions (CoIs). These temporary, independent, non-judicial mechanisms can be set up by the UNSC, the General Assembly, the Human Rights Council, the Secretary-General and the UNHCHR, as well as by regional organisations. ${ }^{48}$ They are designed to address human rights violations by gathering and verifying information, creating a historical record - including specifying the root causes of rights violations - and providing a basis for further investigations, where relevant, in connection to specific alleged violations of international law - usually IHL, ICL or IHRL. ${ }^{49}$ They also contribute to sustainable and ongoing engagements with populations by recommending next steps in terms of redressing violations and establishing mechanisms to provide justice, reparation and accountability. The role of CoIs, as set out by OHCHR, shows

\footnotetext{
${ }^{47}$ Strauss, 'UN Human Rights Council and High Commissioner for Human Rights' pp. 324-25, notes that UPR was ineffective at contributing to mass atrocity prevention in the case of Sri Lanka, though this can largely be explained by the Sri Lankan government's success in framing its actions in ending the civil war as aligned with the War on Terror.

${ }^{48} \mathrm{Coe}$, in this volume, details the investigatory and fact-finding roles of regional human rights institutions.

${ }^{49}$ OHCHR, 'Commissions Of Inquiry And Fact-Finding Missions On International Human Rights And Humanitarian Law: Guidance and Practice', 2015, http://www.ohchr.org/Documents/Publications/CoI_Guidance_and_Practice.pdf, accessed 1 December 2016.
} 
clearly their overlap with R2P concerns: 'they assist in ensuring accountability for serious violations, which is fundamental in order to deter future violations, promote compliance with the law and provide avenues of justice and redress for victims'. ${ }^{50}$ These mechanisms are also particularly appropriate as R2P tools as they are often rhetorically powerful (for instance the Independent Commissions of Inquiry on the 2014 Gaza Conflict and on Human Rights in the Democratic People's Republic of Korea), and establishing them via the Human Rights Council is more straightforward than through the UNSC (where proposals for CoIs can be vetoed). This has meant that the Human Rights Council has been able to act on, for instance, situations in Sri Lanka and Iran, which would have been impossible via the UNSC. ${ }^{51}$ CoIs are a good way to utilise the UN's human rights machinery to contribute to atrocity prevention (via early warning) and documentation. ${ }^{52}$ They could also put situations of concern into a wider context of human rights observance or breach which would give a fuller view of the ways in which human rights abuses are related to atrocity crimes.

A recent development in human rights protection from the UN Secretariat also offers considerable scope for R2P advocates: the Human Rights Up Front initiative (HRuF). This initiative was launched in 2013 as a response to the systemic failures of the UN to fulfil its humanitarian and protection mandates in Sri Lanka as the civil war ended. ${ }^{53}$ The initiative

\footnotetext{
${ }^{50} \mathrm{OHCHR}$, 'Commissions Of Inquiry And Fact-Finding Missions On International Human Rights And Humanitarian Law', p7.

${ }^{51}$ UN Human Right Council, 'OHCHR Investigation of Sri Lanka', http://www.ohchr.org/EN/HRBodies/HRC/Pages/OISL.aspx, accessed 1 December 2016; 'UN Special Rapporteur on the Situation of Human Rights in the Islamic Republic of Iran', http://shaheedoniran.org/, accessed 1 December 2016.

${ }^{52} \mathrm{R} 2 \mathrm{P}$ principles have started to be used to guide HRC Commissions of Inquiry for this purpose: Ban 'Mobilizing Collective Action'.

53 'Report of the Secretary-General's Internal Review Panel on United Nations Action in Sri Lanka', November 2012,
} 
explicitly links the 'human rights' and 'peace and security' pillars at the UN, and aims to make human rights a central focus of the UN's work, with particular priority given to prevention of large-scale human rights abuses. Its vision for the UN is to develop an organisation with an 'activist organisational culture'. ${ }^{54}$ It will do so by:

1: Integrating human rights into the lifeblood of the UN so all staff understand their own and the Organization's human rights obligations. 2: Providing Member States with candid information with respect to peoples at risk of, or subject to, serious violations of human rights or humanitarian law. 3: Ensuring coherent strategies of action on the ground and leveraging the UN System's capacities to respond in a concerted manner. 4: Clarifying and streamlining procedures at Headquarters to enhance communication with the field and facilitate early, coordinated action. 5: Strengthening the UN's human rights capacity, particularly through better coordination of its human rights entities. 6: Developing a common UN system for information management on serious violations of human rights and humanitarian law. ${ }^{55}$

$\mathrm{HRuF}$ is an area of significant focus for the UNSG, and rhetoric around the initiative makes plain the connections between HRuF, human rights and R2P. Deputy Secretary General Jan Eliasson, in presenting the report, indicated that systematic human rights violations have often

http://www.un.org/News/dh/infocus/Sri_Lanka/The_Internal_Review_Panel_report_on_Sri_Lanka.pd f, accessed 1 December 2016.

${ }^{54}$ Global Public Policy Institute, 'With Courage and Coherence: The Human Rights Up Front Initiative of the United Nations', July 2015, http://www.gppi.net/fileadmin/user_upload/media/pub/2015/Kurtz_2015_Courage_and_Coherence_U N_Human_Rights.pdf, accessed 1 December 2016.

${ }^{55}$ ICRtoP, 'Rights Up Front and Civilian Protection'. 
been a precursor to mass atrocities. ${ }^{56}$ In the UNSG's introduction to the 2014 Framework of Analysis for Atrocity Crimes, produced by the Special Advisors on the Prevention of Genocide and the R2P, he states that the HRuF initiative 'means putting human rights, the protection of populations and the prevention of atrocity crimes at the centre of [the UN's] work.' However, despite obvious overlaps in concern, the relationship between HRuF and $\mathrm{R} 2 \mathrm{P}$ remains underdeveloped. And $\mathrm{HRuF}$ is not a panacea - it is an initiative which focuses on the UN Secretariat, so has little formal purchase once a situation has been escalated to the UNSC or the UN General Assembly. It is also a UN initiative rather than the subject of an inter-governmental consensus, which means its success relies on the moral authority which UN actors can claim for their stance. Nevertheless, there is significant potential to augment and extend R2P through engagement with $\mathrm{HRuF}$. HRuF is concerned with both human rights and the protection of civilians, and with both atrocity crimes and man-made humanitarian emergencies. ${ }^{57}$ The initiative joins up human rights protection and atrocity prevention as envisaged in the ICISS report, understanding respect for a broad spectrum of human rights (which most states are already legally obliged to respect) as offering protection against atrocity crimes. It also confronts the political stalemate at the UN over humanitarianism by establishing human rights plans for the UN Secretariat in situations with no active peacekeeping mission (thus extending human rights protection beyond conflict) and by requiring UN officials to act with moral courage and 'appris[e] member states of the situation on the ground even when it is unpalatable to the government or governments concerned or to other parties involved. ${ }^{58}$

\footnotetext{
56 'Deputy Secretary-General's remarks at briefing of the General Assembly on Rights Up Front', 17 December 2013, https://www.un.org/sg/en/content/dsg/statement/2013-12-17/deputy-secretarygenerals-remarks-briefing-general-assembly-rights, accessed 1 December 2016.

${ }^{57}$ Gilmour, 'The Future of Human Rights', p. 241.

${ }^{58}$ Ibid.
} 


\section{The Benefits and Limits of a Human Rights Focus}

The potential for human rights instruments to be used to achieve the goals of $\mathrm{R} 2 \mathrm{P}$ has been acknowledged by the former Special Advisor on R2P, and there are a number of benefits of extending the scope of R2P to encompass human rights more broadly. ${ }^{59}$

Conceptually, reassessing the focus of protection in the R2P has a number of advantages over the atrocity-crime focus. Firstly, broadening R2P's scope conceptualises the people it aims to benefit in more powerful ways - less as victims in need of protection and more as political agents who should be able to claim a wide range of rights from their states, and to have avenues by which to hold their states to account. It shifts the aim of R2P towards empowerment as a form of protection. A human rights focus could still, however, be susceptible to crusading from states in the Global North, and care would need to be taken to challenge narratives which see populations from the Global South as either helpless victims who need saving, or the perpetrators of their own domestic atrocities. Like R2P, a human rights discourse can be used by powerful states to disguise their own complicity in human rights abuses (through arms sales, the propping up of abusive regimes, dominance of an unequal global economic system and so on). ${ }^{60}$

Secondly, a broader focus includes more people and more situations within its remit. It makes it easier to see that R2P, understood as the protection and empowerment of populations, is relevant inside and outside of conflict, and inside and outside states in the Global North

\footnotetext{
${ }^{59}$ Lupel, 'The Responsibility to Protect Principle is not the Problem'.

${ }^{60}$ Makau W. Mutua, 'Savages, Victims, and Saviors: The Metaphor of Human Rights', Harvard International Law Journal, 42/1: 201-45 (2001).
} 
(which tend to see $\mathrm{R} 2 \mathrm{P}$ as a foreign policy issue rather than as something which applies to their own populations). A human rights focus exposes myriad issues within Northern states, particularly after the Brexit referendum in the UK and the conduct of the 2016 US Presidential election. Rather than always being the subject of international attention, states in the Global South could use an expanded focus to hold Northern states to account for their human rights records in the context of R2P. This might go a small way towards levelling the playing field of international politics, and remove some of the perceived imperialist qualities of the discourse of the international protection of populations.

Thirdly, adopting a human rights lens extends R2P concerns both backwards and forwards in time. A rights focus allows the 'prevention' agenda to move further backwards, to enhance the early-warning capabilities currently available by paying attention to a wider range of right issues, such as development, economic inequality and political representation. The Human Rights up Front initiative explicitly aims at this: '[c] ertain human rights violations including economic, social and cultural rights - can be a clear indicator of a wider pattern of serious violations. Marginalization and exclusion are often the first warning signs of worse to come. By staying attuned to these issues in all settings, a UNCT [UN Country Team] can identify concerns at an earlier stage and use HRuF to get early support from the wider UN system to address the situation effectively' ${ }^{61}$ A rights lens should also extend the pillar three intervention agenda forwards in time. At present, R2P can be used as a quick 'fix' to prevent or bring an end to atrocities, as in the case of Libya. Making human rights central to the implementation of R2P would offer a way, if intervention was used under pillar three, to hold

\footnotetext{
61 'Human Rights up Front: An Overview', https://undg.org/wp-content/uploads/2015/09/Overviewof-Human-Rights-up-Front-2015-07-24.pdf, accessed 10 December 2016.
} 
interveners to account to assist in (re)building a state in which human rights are protected and can be exercised. ${ }^{62}$

Institutionally, utilising human rights mechanisms (whether or not R2P is conceptualised more broadly) could help to break the current impasse at the level of the UNSC. A trend towards states 'forum shopping' for forums in which investigations into alleged atrocity crimes can be launched can be observed in contemporary international politics. The Human Rights Council has received some focus, particularly after the perceived success of its CoI on the Syria situation. ${ }^{63}$ Samantha Power, US Permanent Representative to the UN, explains that: '[i]t's a Darwinian universe here [at the UN]. If a particular body reveals itself to be dysfunctional, then people are going to go elsewhere ... [a]nd if that happened for more than Syria and Ukraine and you started to see across the board paralysis ... it would certainly jeopardise the security council's status and credibility and its function as a go-to international security arbiter' ${ }^{64}$ This potential to provoke the UNSC to take up its peace and security responsibilities once again, via the use of alternative mechanisms to pursue R2P goals, is intriguing and necessary (as the UNSC is still the UN's most powerful body, best placed to exercise pillar three R2P responsibility if agreement can be reached among the P5), but faces hurdles. The HRC is still, even without a veto system, limited by state interests - for instance,

\footnotetext{
${ }^{62}$ Keranen 'What Happened to the Responsibility to Rebuild?'.

${ }^{63}$ Independent International Commission of Inquiry on the Syrian Arab Republic, http://www.ohchr.org/EN/HRBodies/HRC/IICISyria/Pages/IndependentInternationalCommission.aspx , accessed 10 December 2016. This has now led to the creation, by the UN General Assembly, of the International, Impartial and Independent Mechanism for Syria, which the OHCHR is in the process of establishing.

${ }^{64}$ Julian Borger and Bastien Inzaurralde, 'Russian vetoes are putting UN security council's legitimacy at risk, says US', 23 September 2015, https://www.theguardian.com/world/2015/sep/23/russianvetoes-putting-un-security-council-legitimacy-at-risk-says-us, accessed 10 December 2016.
} 
the UK is accused of blocking a powerful independent international CoI on Yemen. ${ }^{65}$ And the HRC has no power to implement its recommendations and decisions. ${ }^{66}$ But it does have significant rhetorical power, alongside the potential to provoke more robust UNSC action in the face of serious violations of human rights by challenging the Security Council's monopoly over the UN's peace and security work. It also, because of the voting procedures for members of the Council, has the ability to bypass UNSC hurdles by precluding some states from membership. ${ }^{67}$

There are various important limits or drawbacks of broadening the focus of protection in R2P. The obvious argument against a rights lens is that if a narrow $\mathrm{R} 2 \mathrm{P}$ has struggled to take root, a broader focus can only offer less protection by diluting the power of the norm. As Evans has argued, if R2P 'is to be about protecting everybody from everything, it will end up protecting nobody from anything' ${ }^{68}$ This assumes, however, that R2P is currently doing more good than harm - a claim which would be hard to substantiate. There has been little political will evident from states to act on R2P (versus talking about R2P), so although states may well resist a more expansive vision of R2P, particularly those opposed to intervention in just about any circumstances, it is not clear how this would result in more harm than we currently tolerate. The practice of seeking authorisation for intervention via the UNSC should act as a bulwark against any state that tried to use an expanded focus of R2P as an excuse to intervene unjustifiably.

\footnotetext{
${ }^{65}$ Jamie Doward, 'UK accused of blocking UN inquiry into claim of war crimes in Yemen' 24 September 2016, https://www.theguardian.com/world/2016/sep/24/yemen-britain-human-rightsinquiry, accessed 6 December 2016.

${ }^{66}$ Hehir, 'From Human Security to the Responsibility To Protect'.

${ }^{67}$ For instance, Russia failed in its bid to be re-elected to the Council in October 2016.

${ }^{68}$ Gareth Evans, The Responsibility to Protect: Ending Mass Atrocity Crimes Once and For All (Washington, D.C.: Brookings Institution, 2008), p. 65.
} 
A more percipient criticism is that adopting a rights lens might be equivalent to fiddling while Rome burns. An expansion of focus as described above does little to challenge the structures and institutions of international society that have failed so protect so many times since a responsibility to protect was acknowledged. A more radical position may be required to see radical change - for instance, the decentralisation of human rights work away from international institutions and towards the populations claiming those rights, possibly via a rejuvenation of the human security agenda's focus on empowering civil society. ${ }^{69}$ Indeed, the ICISS report called for a more encompassing vision of security than that which states and international institutions tend to operate with: ' $[\mathrm{t}]$ he traditional, narrow perception of security leaves out the most elementary and legitimate concerns of ordinary people regarding security in their daily lives. It also diverts enormous amounts of national wealth and human resources into armaments and armed forces, while countries fail to protect their citizens from chronic insecurities of hunger, disease, inadequate shelter, crime, unemployment, social conflict and environmental hazard'. ${ }^{70}$

However, such a radical position is nigh on impossible within the current framework. While human rights norms might appear to be deeply embedded in the law, institutions and practices of states and international society, the distribution of resources tells a rather different story. Human rights work is chronically under-funded within the UN at present, with just over $3 \%$ of the UN's regular budget allocated to human rights. The budget allocated to OHCHR is not enough to implement the human rights mandates established by the General Assembly and the

\footnotetext{
${ }^{69}$ On human rights politics, see Joe Hoover, Reconstructing Human Rights (Oxford, Oxford University Press, 2016). On R2P and human security, see Hehir, 'From Human Security to the Responsibility To Protect'.

${ }^{70}$ ICISS, The Responsibility to Protect, p. 15.
} 
Human Rights Council. ${ }^{71}$ Extra-budgetary funds already have to be found to fund OHCHR's mandated work, and expanding its work to cover R2P would require further voluntary funding to be sought. Securing resources for human rights work would therefore have to be a priority for R2P advocates if the focus of the R2P was to be broadened.

\section{Conclusion}

The core argument made in the article is that $\mathrm{R} 2 \mathrm{P}$ has not succeeded in offering protection to populations, despite its focus being narrowed to atrocity crimes in order to gain state support. The atrocity crime focus was shown to be conceptually as well as practically flawed, as it fails to appreciate both the harms which take place outside the 'atrocity' framing, and the nature of the actors perpetrating and experiencing harm. One response to this would be to give up - to abandon R2P to the scrapheap of grand visions which have failed to change the basic nature of international politics. This article, however, explored an alternative - stretching the focus of R2P back to the broader vision found within the ICISS report. There is some evidence to suggest that adopting a human rights lens and seeking to utilise human rights mechanisms when undertaking R2P work could lead to more people being protected, and indeed empowered, through the R2P doctrine. But this relies on states and international organisations taking pillars one and two more seriously (and R2P advocates pressing them to do so). Pillar three would become even weaker as the link between pillars one and three would be partially severed, insofar as only some specific breaches of human rights obligations should trigger an international responsibility to protect. If states routinely fail in their pillars one and two responsibilities as well as in their pillar three responsibility, then no adjustment of focus will

\footnotetext{
${ }^{71}$ OHCHR, 'OHCHR's Funding and Budget', http://www.ohchr.org/EN/AboutUs/Pages/FundingBudget.aspx, accessed 10 December 2016.
} 
save the R2P. But we have not yet reached the point of giving up, and an effort to reinvigorate $\mathrm{R} 2 \mathrm{P}$, via a change to the focus of protection, offers some significant potential benefits. Plus, politically, seeking to enhance the powers of citizens everywhere to make rights claims from their states is considerably more progressive than campaigning only for protections from atrocity. 